\title{
The occurrence of post-gamma protein in urine: a new protein abnormality ${ }^{1}$
}

\author{
ELIZABETH A. BUTLER AND F. V. FLYNN \\ From the Department of Clinical Pathology, University College Hospital, London
}

SYNOPSIS As a result of studying the urine proteins of 223 individuals by starch gel electrophoresis a new urine protein fraction has been recognized. On starch gel electrophoresis at alkaline $p \mathrm{H}$ the new fraction moves to a position appreciably nearer the cathode than the slowest-moving $\gamma$-globulin. in normal serum. A small amount of this post- $\gamma$ protein was found in the urine of 46 patients with clinical proteinuria, including 19 with the Fanconi syndrome and nine with multiple myeloma

The nature, origin, and clinical significance of post- $\gamma$ protein is discussed.

The proteins that occur in urine have received much less attention than those in serum, probably because the time-consuming step of preliminary concentration is usually necessary for their study. Even so there is a considerable literature dealing with the electrophoresis of urinary proteins in man (Longsworth and MacInnes, 1940; Luetscher, 1940; Gutman, Moore, Gutman, McClellan, and Kabat, 1941; Blackman and Davis, 1943; Moore, Kabat, and Gutman, 1943; Routh, Knapp, and Kobayashi, 1948; Farnsworth and Ruppenthal, 1951; Macheboeuf, Rebeyrotte, and Brunerie, 1951; Parviainen, Soiva, and Ehrnrooth, 1951; Rigas and Heller, 1951; Rundles, Cooper, and Willett, 1951; Rifkin and Petermann, 1952; Hauser, 1953; Jahnke and Scholtan, 1953; Schmidt, 1953; Slater and Kunkel, 1953; Soulier, 1953; Suenderhauf and Wunderly, 1953; Wiedermann, 1953; Boyce, Garvey, and Norfleet, 1954; Feruglio and Rimini ,1954; Wunderly and Caspani, 1954; Alvarez and de la Gandara, 1955; Del Bianco, 1955; Moeller and Steger, 1955; Osserman and Lawlor, 1955; Prill and Steger, 1955; Löwgren, 1956; Sellers and Marmorston, 1956; Engle, Woods, and Pert, 1957; Jim, 1957; Owen and Rider, 1957; Wolvius and Verschure, 1957; Angeli, 1958; Broch and Brodwall, 1958; Flynn and Stow, 1958; Hartmann, Lagrue, and Moretti, 1958; Heremans, 1958; Nedbal and Seliger, 1958; Schneiderbaur and Rettenbacher, 1958; Webb, Rose, and Sehon, 1958; Biserte, Breton, and Havez, 1959; Cirla, Salteri, and Bonomo, 1959; Hartmann, Lagrue, Raoult, Binet, and Milliex, 1959; Riva,

${ }^{1}$ Based on a paper read at the combined meeting of the Association of Clinical Pathologists and of the Association of Clinical Biochemists in London on 3 October 1959.
1959; Salteri, Cirla, and Bonomo, 1959). Thesê studies have established that in all the conditionf usually associated with proteinuria the lower molecular weight plasma proteins escape into thפ urine preferentially; thus albumin is predominan and the proportions of $a_{1}$-globulin and the non $\frac{5}{5}$ lipid $\beta$-globulin are relatively high. In multip myeloma the low molecular-weight Bence-Jones protein usually predominates, producing a pea somewhere between the $\alpha_{2}$ - and $\gamma$-globulin positions

In 1958, Butler and Flynn reported that the slight proteinuria accompanying renal tubular disorders was often distinctive, being characterized on paper. electrophoresis by the presence of a high proportion of $a_{2}$-globulin. With the object of defining this type of proteinuria more specifically it was decided to. study the urinary proteins from cases of the Fancorf syndrome and related disorders by starch get electrophoresis. With this technique it was found that the large $a_{2}$-globulin component on paper corresponded to fractions migrating between the $\beta$-globulin and albumin positions on starch gel. Ifs addition it was found that many of the specimens contained a small amount of a protein whic migrated more slowly than the slowest $\gamma$-globulimp detectable in normal serum. The present con munication is concerned with the occurrence of this previously undescribed post- $\gamma$ protein.

MATERIAL AND METHODS

Fresh urine specimens and in many cases samples clotted venous blood were obtained from 193 patients and relevant data concerning these is given in Table $\$$ For control purposes six individual samples were obtained 
from healthy adults and pooled normal urines were collected from 12 adult males and from 12 adult females.

Single specimens of urine of about $200 \mathrm{ml}$. were examined in most instances, but the volume concentrated varied between $5 \mathrm{ml}$. and 3 litres. In 31 cases, including 20 where a post- $\gamma$ protein was subsequently found in the urine, further specimens were obtained for confirmation of the findings. In all, 244 urine specimens were examined.

The urine specimens were filtered, the volume recorded, and the total protein measured by a modification of the turbidometric method of Kingsbury, Clark, Williams, and Post (1926). The urine proteins were subsequently concentrated, if possible to a level of approximately 2 to $3 \mathrm{~g} .100 \mathrm{ml}$., by one of two methods: the earlier samples were dialysed at $4^{\circ} \mathrm{C}$. in Visking tubing against a saturated solution of gum acacia and the later specimens were ultrafiltered in similar tubing at room temperature as described by Grant (1957). Thiomersal B.P. was added as a preservative in the latter case, enough being added to give a final concentration of $10 \mathrm{mg} . / 100 \mathrm{ml}$. The brown concentrate was centrifuged when a precipitate was present and the supernatant used for electrophoresis. The urine specimens were processed as swiftly as possible but if they had to be left at any stage they were stored at either $4^{\circ} \mathrm{C}$. or at $-20^{\circ} \mathrm{C}$.

All the concentrates were examined by paper electrophoresis, using the qualitative technique of Flynn and de Mayo (1951), and by starch gel electrophoresis after the method of Smithies (1955). A few were also examined by electrophoresis on cellulose acetate strips using the method of Kohn (1957a). Two-dimensional electrophoresis, involving separation on cellulose acetate followed by fractionation on starch gel, was carried out according to the principles of the method of Poulik and Smithies (1958); tris-citrate/borate discontinuous buffer (Poulik, 1957) was used for the analysis in the second dimension.

In 12 instances immuno-electrophoresis was carried out. This was performed by diffusion into agar from strips cut from the starch gels, the detailed technique being similar to that of Kohn (1957b) for immunodiffusion from cellulose acetate strips. The antiserum used was a horse antihuman serum prepared by the Pasteur Institute.

In certain of the patients additional routine investigations were carried out, namely, microscopical examination of the centrifuged urine deposit and determination of the serum and urine calcium, plasma alkaline phosphatase, and blood urea.

\section{RESULTS}

Of the 244 urine specimens examined, 159 had protein detectable by the sulphosalicylic acid test. After concentration all had protein detectable on the starch gels and all but two, originally very dilute specimens, had protein demonstrable on the paper strips. The paper electrophoretic strips showed a whole spectrum of patterns, but four main categories could be recognized, examples of which are shown
TABLE I

CASES INVESTIGATED

$\begin{array}{ll}\text { No. of } & \text { No. with } \\ \text { Patients } & \text { Proteinuria }\end{array}$

Patients with Renal Tubular Dysfunction

Fanconi syndrome

Adult type

Acquired

Cystinosis

Dominant type

With cirrhosis but no cystinosis

Renal tubular rickets

Renal tubular acidosis

Hartnup disease

Cystinuria

Organic-aciduria syndrome

Atypical renal tubular defects

Wilson's disease

Severe potassium depletion

Sodium-losing nephritis

Pituitary diabetes insipidus

Galactosaemia

Patients with Conditions Commonly

Associated with Proteinuria

Urinary tract infections

Nephritis Type 2

Chronic nephritis

Diabetic nephropathy

Nephrosclerosis with malignant hypertension

Severe pre-eclamptic toxaemia

Disseminated lupus erythematosis

Congenital hypoplastic kidneys

Congestive cardiac failure

Nephritis Type 1

Polyarteritis

Orthostatic proteinuria

Patients with Neoplastic Disease

Multiple myeloma

Carcinoma of bronchus

Hodgkin's disease

Carcinoma of breast

Carcinoma of bladder

Carcinoma of other sites

Lymphocytic lymphoma

Lymphatic leukaemia

Cordoma

Patients with Miscellaneous Other Conditions

Sarcoidosis

Cirrhosis of liver

Idiopathic nephrocalcinosis

Aldrich's syndrome

Idiopathic steatorrhoea

Renal calculi

Idiopathic hypercalcuria

Hyperparathyroidism

Vitamin D intoxication

Idiopathic osteoporosis

Septic arthritis

Acute pancreatitis

Acute pericarditis

Bronchiectasis

Pulmonary tuberculosis

Tuberculous adenitis

Iron-deficiency anaemia

Duodenal diverticulae with megaloblastic

anaemia

Thalassaemia

Sickle-cell anaemia

Obstructive jaundice

Purgative addict with potassium depletion

Recovering lead poisoning

Polymyositis

Hashimoto's thyroiditis

Von Gierke's disease

Pink disease

Analbuminaemia 

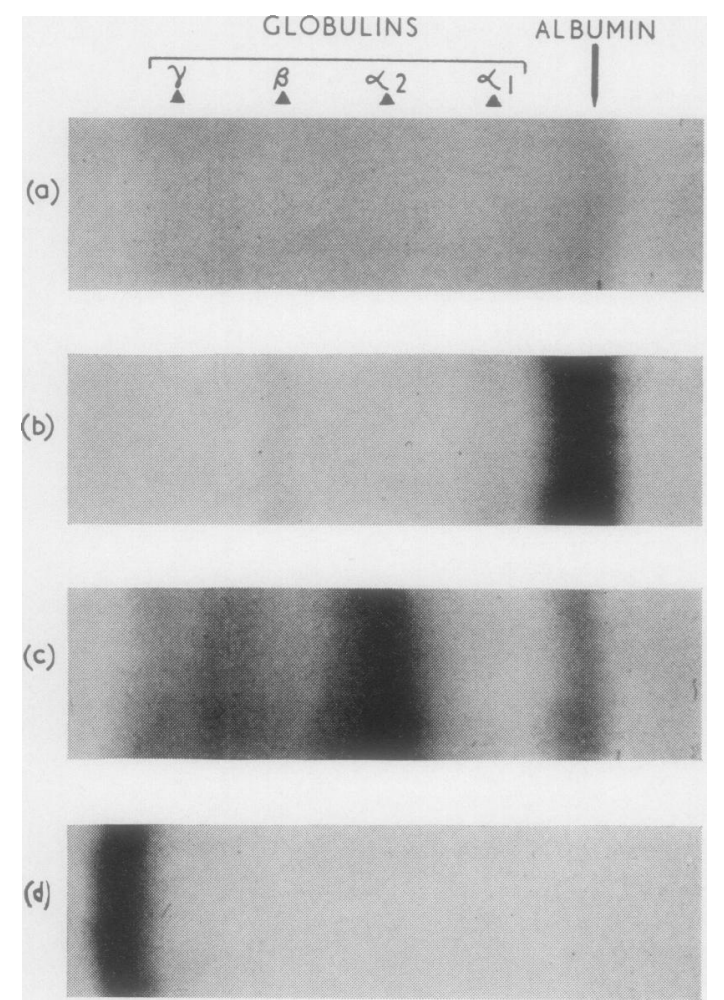

FIG. 1. Examples of urine protein patterns on filter paper electrophoresis.

(a) Normal: urine from healthy adult.

(b) Glomerular proteinuria: urine from patient with Type 2 nephritis.

(c) Tubular proteinuria: urine from patient with organicaciduria syndrome.

(d) Bence-Jones protein: urine from patient with multiple myeloma.

in Fig. 1. The corresponding starch gel patterns are shown in Fig. 2. The starch gel patterns from the normal controls showed small amounts of albumin predominating over lesser amounts of a post-albumin fraction and traces of $\beta$ and pre-albumin fractions. The 85 specimens from patients without clinical proteinuria were in most instances similar; seven, which were either exceptionally dilute or were concentrated less, showed only an albumin band, but others had in addition a trace of normal $\gamma$ globulin and a diffuse band in the slow $a_{2}$ region. The starch gel patterns of the 159 urines from patients with clinical proteinuria were more variable. Generally, those that had a glomerular leak type of pattern on paper electrophoresis showed a vast preponderance of albumin, a large amount of $\beta$ globulin, and lesser amounts of post-albumin, $\gamma$-globulin, and pre-albumin fractions. Those that had the tubular proteinuria pattern on paper showed: a relatively small amount of albumin and a higher? proportion of post-albumins and protein migrating between the $\beta$ - and fast- $a_{2}$-globulin positions. Those $\frac{\bar{c}}{\bar{n}}$ with Bence-Jones protein usually showed a large proportion of one or two proteins situated in the $\gamma, \beta$, $a \beta$, or slow $\alpha_{2}$ region superimposed on anes otherwise normal type of pattern. In two cases theBence-Jones protein occupied a post- $\gamma$ position: The interesting finding, however, was the detection $\vec{w}$ of a trace quantity of a post- $\gamma$ protein in some of the gel patterns from patients without myeloma. Sucho a post- $\gamma$ protein is shown in Fig. 3. A total of $4 \sigma_{\triangle}$

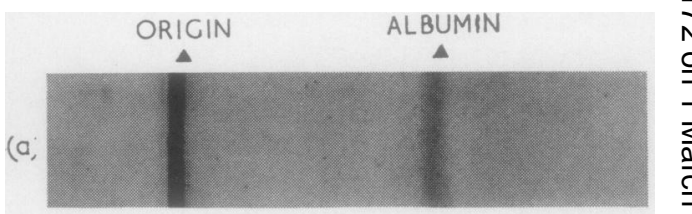

(b)
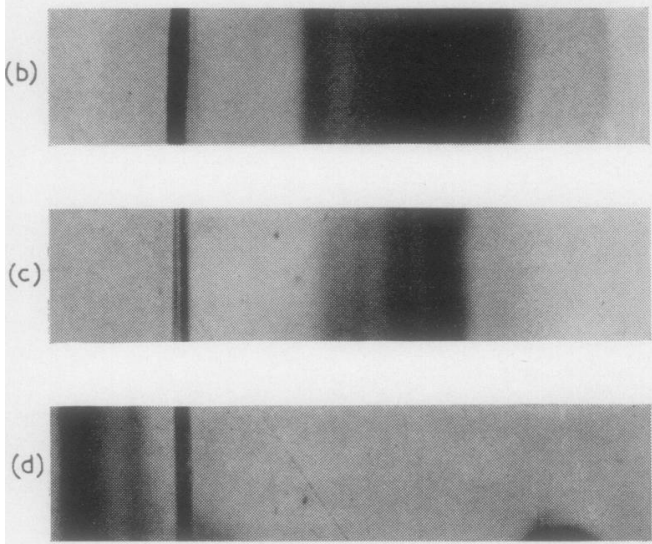

FIG. 2. Examples of urine protein patterns on starch gel electrophoresis.

(a) Normal: urine from healthy adult.

(b) Glomerular proteinuria: urine from patient with Type 20 nephritis.

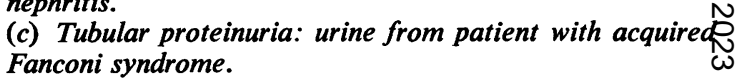

(d) Bence-Jones protein: urine from patient with multiple myeloma.

patients (22 female and 24 male) had a post- $\gamma^{+}$ protein in the urine. In most instances this band was found at a distance from the insertion equal tof twice that of the slowest-moving component of the normal $\gamma$-globulin, but in a few it occupied an $\varrho$ intermediate position. In one of the patients a post- $\mathcal{2}$ protein was also detected in the neat serum on one 


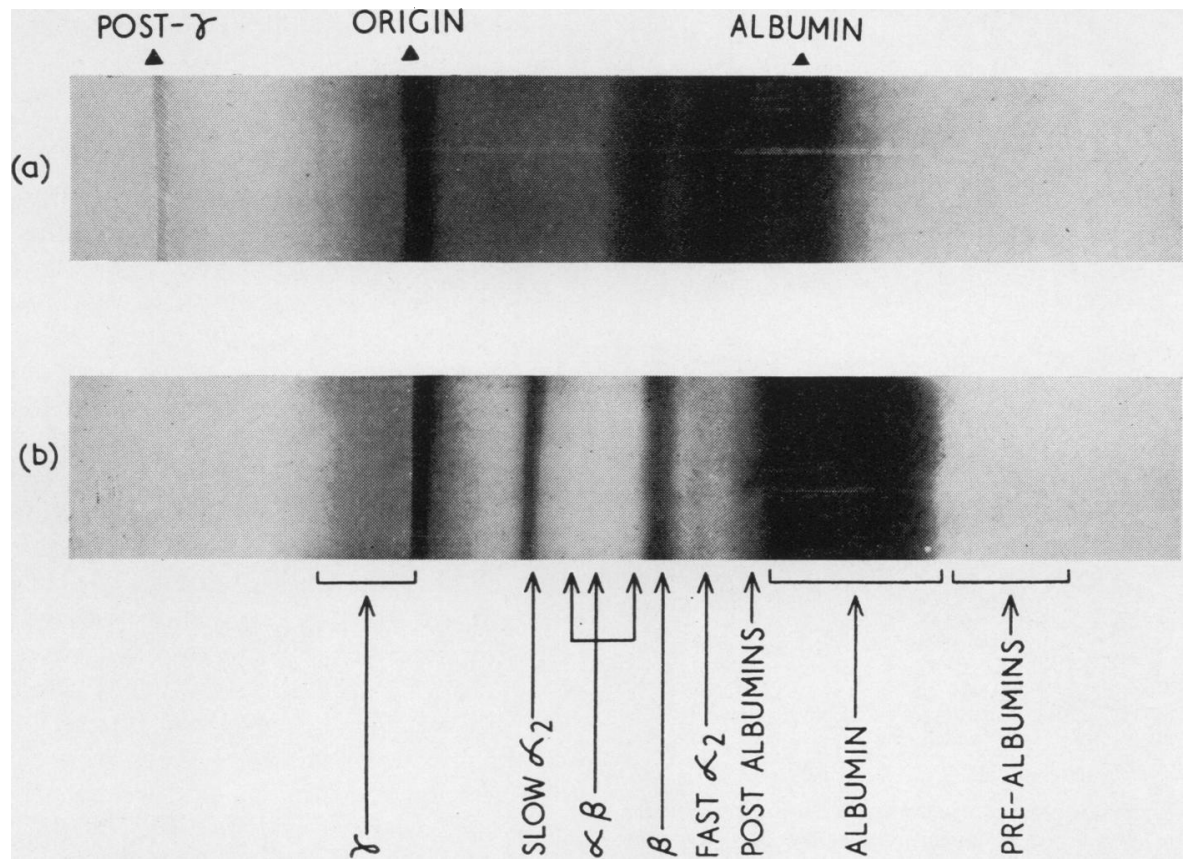

FIG. 3. Urine showing post- $\gamma$ protein on starch gel electrophoresis. (a) Urine from patient with adult Fanconi syndrome. (b) Serum from normal healthy adult.

occasion. The diagnoses among the patients with a post- $\gamma$ protein in the urine are shown in Table II. It is noteworthy that 27 , i.e., $79 \%$, of the 34 patients who had renal tubular dysfunction with proteinuria, showed the post- $\gamma$ band.

Electrophoresis on cellulose acetate of some of the urine concentrates showing a relatively high proportion of post- $\gamma$ protein on the starch gels revealed

TABLE II

PATIENTS WITH POST $-\gamma$ PROTEIN IN THE URINE

$\begin{array}{ll}\text { No. with } & \text { No. } \\ \text { Post }-\gamma & \text { Examined } \\ \text { Band } & \end{array}$

Fanconi syndrome

Adult type

Acquired

Cystinosis

Dominant type

Multiple myeloma

Renal tubular acidosis

Congenital hypoplastic kidneys

Atypical renal tubular defects

Organic-aciduria syndrome

Urinary tract infection

Sarcoidosis

Severe potassium depletion

Chronic nephritis

Hodgkin's disease

Primary biliary cirrhosis

Polyarteritis the presence of a trace quantity of protein migrating more slowly than the slowest $\gamma$-globulin detectable in normal serum. Two-dimensional electrophoresis confirmed the identity of the post- $\gamma$ fractions on cellulose acetate and starch gel.

The protein content and extent of concentration of the urines showing the post- $\gamma$ protein is compared with similar data applicable to the remainder of the specimens in Fig. 4. This shows that the post- $\gamma$ protein was usually found in the less marked proteinurias and that its detection was not simply a result of the urine having been concentrated to a greater extent.

The results of microscopy of the urine deposit in 60 cases indicated that there was no relation between the presence of a post- $\gamma$ protein and the presence of red cells, pus cells, or casts. Attempts to correlate the presence of this protein with the level of the serum calcium, urine calcium, and plasma alkaline phosphatase were equally unsuccessful.

Examples of the results of immuno-diffusion from starch gel electrophoretic strips are shown in Fig. 5. This shows that in a urine with a marked post- $\gamma$ protein there is some precipitation beyond the limit of the normal $\gamma$-globulin, but the centre of the arc does not correspond in position with the post- $\gamma$ band. In the serum from the same patient, in which 


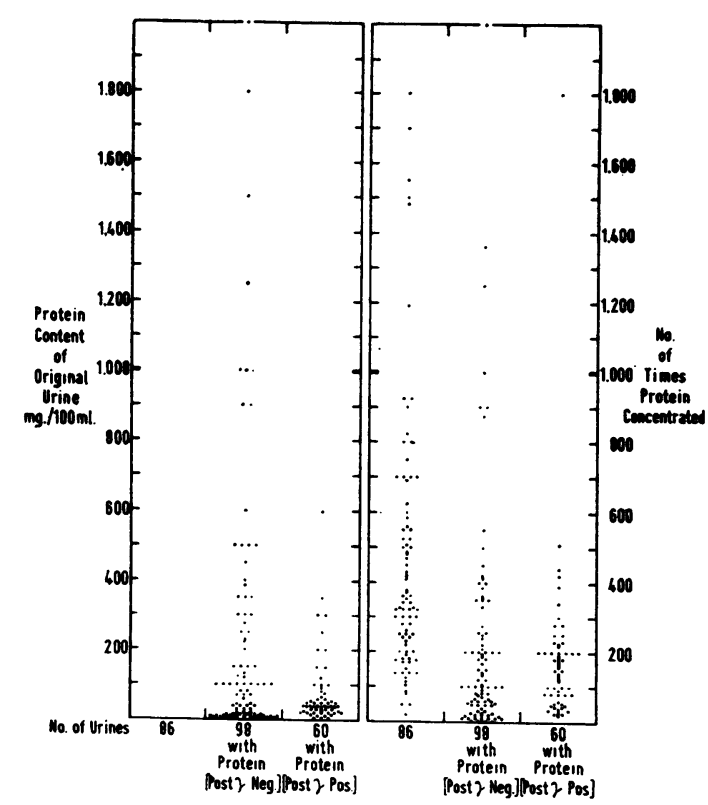

FIG. 4. Diagram showing protein content of original urine specimens and extent of subsequent concentration process. (Median values for the six columns from left to right $=0$, $65,40,333,100,155$ respectively.) a post- $\gamma$ band was discernible, a similar result is seen.

\section{DISCUSSION}

The finding of post- $\gamma$ protein in the urine was quiteunexpected and led us to consider whether it waso an artefact, whether it was a minor component of normal urine, and whether it was derived from 5 plasma or from the urinary tract.

The new fraction might have resulted from de- $\vec{\omega}$ naturation of the urine protein during the cons? centration process or during storage. Thiomersato cannot be incriminated as its use showed no corre- $\vec{p}$ lation with the presence of the post- $\gamma$ band. Similarlyiv the extent and manner of the concentration process $\overrightarrow{-}$ and the duration and conditions of storage bore $\mathrm{no}^{\mathrm{N}}$

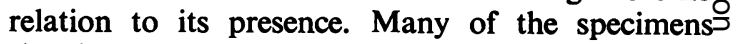
showing a post- $\gamma$ fraction were in fact subjected to ${ }_{7}^{-}$ starch gel electrophoresis within 24 hours of collec tion and without having been frozen. The presences of unusual denaturation factors in the urine itself was excluded by showing that the starch gel patterno of normal serum was quite unaltered when it had been diluted with ultrafiltered urine from a patient with the adult Fanconi syndrome and recon-s

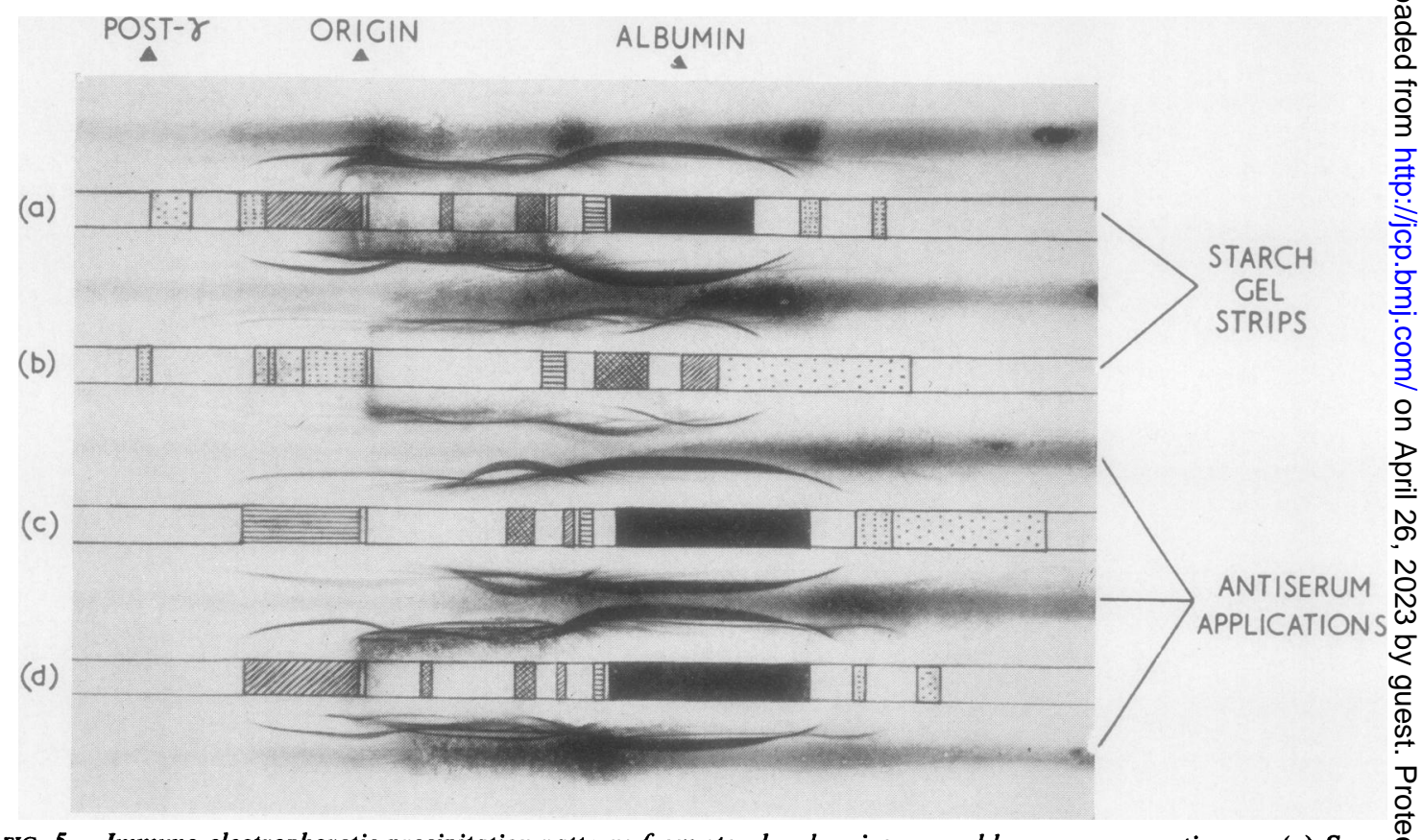

FIG. 5. Immuno-electrophoretic precipitation patterns from starch gels using normal human serum antiserum. (a) Serumß with post- $\gamma$ protein: from patient with cystinosis. (b) Urine with post- $\gamma$ protein: from patient with cystinosis. (c) Urine $\mathbb{\Omega}^{\circ}$ without post- $\gamma$ protein: from patient with congestive cardiac failure. $(d)$ Normal serum: from healthy adult.

The position of the protein bands on the strips of starch gel is indicated in diagramatic form, correction having been made for the shrinkage that occurredon staining; the density of shading indicates the relative concentration of the protein fractions 
centrated exactly as a specimen of urine. The fact that the findings were reproducible on subsequent specimens also indicates that denaturation is an unlikely explanation.

The data concerning the degree of concentration of the urines (Fig. 4) show that the detection of a post- $\gamma$ protein cannot be attributed simply to a greater degree of concentration of the specimens in question. It is clear, however, that this protein could easily have been missed if the process had not been carried far enough, as the amounts present were in all cases very small. The specimens of pooled normal urine were concentrated approximately 1,000 -fold and yet no post- $\gamma$ band was visible, so its detection at much lower degrees of concentration must be considered pathological.

Following the work of Grant $(1957,1959)$ on normal urine proteins, consideration was next given to whether this protein was a plasma protein that had reached the urine via the glomerulus, or whether it might be a protein that had been added to the urine from genito-urinary tract secretions or from breakdown of free cellular elements. Its occurrence in patients of both sexes and in infants of 3 and 7 months indicated that a genital origin was unlikely. Similarly, the absence of any relationship to the findings in the urine deposit made it improbable that it represented a breakdown product of red cells, pus cells, or casts. Free haemoglobin, detected by benzidine staining, was found in specimens both with and without post- $\gamma$ protein, confirming that a red cell origin was unlikely. Immuno-electrophoresis failed to establish that the post- $\gamma$ protein was derived from plasma; the immuno-precipitation patterns from the starch gels showed arcs extending beyond the normal $\gamma$ region but these did not correspond with the post- $\gamma$ band. In two of the patients with tubular disorders direct evidence in favour of a plasma origin for this protein was obtained; in one, with an unusually high concentration of post- $\gamma$ protein in the urine, a post- $\gamma$ protein was detected in the starch gel pattern of the neat serum, while in the other such a protein was demonstrated after concentrating the serum by freeze drying. In neither case did the post- $\gamma$ band in the serum move as far back towards the cathode as in the urine, but the higher concentration of normal $\gamma$-globulin in the serum might well have influenced its migration in this way, just as one haemoglobin can influence the migration of another (Butler, Flynn, and Huehns, 1960). It seems likely, therefore, that post- $\gamma$ protein comes from the blood.

Assuming that this protein leaks into the urine via the glomerulus, what is its origin and clinical significance? A review of the patients concerned revealed two points: that all were liable to have some disturbance of bone metabolism, and that nearly all had conditions that are occasionally, if not invariably, associated with renal tubular dysfunction. Evidence that this protein could be derived from bone was sought, but there was no correlation between its presence or absence and the results of calcium and alkaline phosphatase determinations. There was no relationship either with the administration of vitamin D or alkalis. To establish a possible association with renal tubular dysfunction, evidence of resorption defect was sought in some of those patients where it would have been unexpectedas in the two patients with sarcoidosis-but tests such as amino-acid chromatography showed no abnormality. All the patients who had the tubular proteinuria pattern had a post- $\gamma$ fraction on starch gel but some patients with a glomerular proteinuria pattern had a similar band.

Other possibilities considered were that this protein might represent an unusual metal-protein complex or a genetically determined protein variant. The former was shown to be unlikely by an experiment in which the post- $\gamma$ protein in a urine concentrate remained unaltered after dialysis against a large volume of buffer solution containing $0.6 \%$ ethylenediaminetetraacetic acid (Aronsson and Grönwall, 1957). As some of the patients with the post- $\gamma$ protein were related, inheritance of a protein variant seemed a possibility. In three of the patients, however, one with potassium depletion, one with sarcoidosis, and one with a urinary tract infection, the post- $\gamma$ protein disappeared from the urine as the patient recovered.

While the nature and origin of most of the post- $\gamma$ globulins remain uncertain, in at least two of the patients with multiple myeloma the findings on paper electrophoresis taken in conjunction with the result of the heat test made it certain that the post- $\gamma$ globulin was in fact a Bence-Jones protein. It may well have represented a minor Bence-Jones component in five of the remaining seven cases of myeloma with a post- $\gamma$ band. Possibly the post- $\gamma$ fraction represented an abnormal protein in all the cases, but the fact that it did not react with the antiserum to normal serum proteins cannot be accepted as proof. It seems reasonable to assume that the post- $\gamma$ fraction represented a similar protein in the different patients, for while the mobility and compactness of the post- $\gamma$ protein were variable, when two of the urines with apparently different post- $\gamma$ proteins were mixed only a single band was obtained. Such differences as we have found might be due to the variation in concentration of normal $\gamma$-globulins.

Whatever its nature and origin, the post- $\gamma$ protein is associated most frequently with conditions dis- 
playing gross forms of renal tubular dysfunction. Our results do not permit us to give an estimate of its frequency, for although we have studied almost the complete spectrum of conditions associated with proteinuria, an undue proportion of patients with malignant disease and renal tubular disorders have been included as our ideas as to its aetiology have developed. Further, we may well have missed it in some of the urine specimens because of inadequate concentration. It seems likely, however, that its occurrence is relatively rare.

We wish to thank the physicians at University College Hospital, particularly Professor C. E. Dent, for providing us with most of the specimens, and also Sir Wilfred Sheldon and Drs. J. R. Nassim, S. W. Stanbury, J. M. Stowers, and J. M. Walshe for sending us specimens from patients with rare conditions. We also thank Dr. E. R. Huehns for help with the cellulose acetate electrophoresis, Mr. V. K. Asta for the diagram, and Mr. A. C. Lees for the photographs.

\section{REFERENCES}

Alvarez, J. G., and de la Gandara, J. O. (1955). Rec. Trav. chim. Pays-Bas, 74, 591.

Angeli, G. (1958). Minerva ginec. (Torino), 10, 399.

Aronsson, T., and Grönwall, A. (1957). Scand. J. clin. Lab. Invest., 9, 338.

Biserte, G., Breton, A., and Havez, R. (1959). Arch. franç. Pédiat., 16, 634.

Blackman, S. S., and Davis, B. D. (1943). J. clin. Invest., 22, 545.

Boyce, W. H., Garvey, F. K., and Norfleet, C. M. (1954). Ibid, 33, 1287.

Broch, O. J., and Brodwall, E. (1958). Acta med. scand., 160, 353.

Butler, E. A., and Flynn, F. V. (1958). Lancet, $2,978$.

,- , and Huehns, E. R. (1960). Clin. chim. Acta, 5, 571.

Cirla, E., Salteri, F., and Bonomo, E. (1959). Rass. Fisiopat. clin. ter., 31, 713.

Del Bianco, C. (1955). Arch. Ostet. Ginec., 60, 121.

Engle, R. E., Woods, K. R., and Pert, J. H. (1957). J. clin. Invest., 36,888 .

Farnsworth, E. B., and Ruppenthal, N. C. (1951). J. Lab. clin. Med., $38,407$.

Feruglio, F. S., and Rimini, R. (1954). Minerva nefrol. (Torino), 1, 155.

Flynn, F. V., and de Mayo, P. (1951). Lancet, 2, 235.

$\longrightarrow$, and Stow, E. A. (1958). J. clin. Path., 11, 334.

Grant, G. H. (1957). Ibid, 10, 360 .

- (1959). Ibid, 12, 510 .

Gutman, A. B., Moore, D. H., Gutman, E. B., McClellan, V., and Kabat, E. A. (1941). J. clin. Invest., 20, 765.

Hartmann, L., Lagrue, G., and Moretti, J. (1958). Rev. franç. Et.

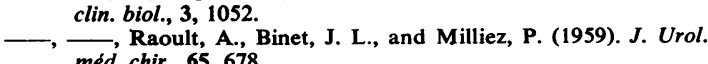

Hauser, W. (1953). Ärztl. Wschr., 8, 840.

Heremans, J. (1958). Clin. chim. Acta, 3, 34.
Jahnke, K., and Scholtan, W. (1953). Dtsch. Arch. klin. Med., 200 821.

Jim, R. T. S. (1957). Blood, 12, 56.

Kingsbury, F. B., Clark, C. P., Williams, G., and Post, A. L. (1926) J. Lab. clin. Med., 11, 981.

Kohn, J. (1957a). Clin. chim. Acta, 2, 297.

- (1957b). Nature (Lond.), 180, 986.

Longsworth, L. G., and MacInnes, D. A. (1940). J. exp. Med., 71우 77.

Löwgren, E. (1956). Acta med. scand., 153, 333.

Luetscher, J. A. (1940). J. clin. Invest., 19, 313.

Macheboeuf, M., Rebeyrotte, P., and Brunerie, M. (1951). Bull. Soc.. Chim. biol. (Paris), 33, 1543.

Moeller, J., and Steger, J. (1955). Z. klin. Med., 153, 205.

Moore, D. H., Kabat, E. A., and Gutman, A. B. (1943). J. clin. Invest 22, 67.

Nedbal, J., and Seliger, V. (1958). J. appl. Physiol., 13, 244.

Osserman, E. F., and Lawlor, D. P. (1955). Amer. J. Med., 18, 462

Owen, J. A., and Rider, W. D. (1957). J. clin.Path., 10, 373. iv

Parviainen, S., Soiva, K., and Ehrnrooth, C. A. (1951). Scand. J. clin. Lab. Invest., 3, 282.

Poulik, M. D. (1957). Nature (Lond.), 180, 1477.

, and Smithies, O. (1958). Biochem. J., 68, 636.

Prill, H. J., and Steger, J. (1955). Arch. Gynäk., 187, 93.

Rifkin, H., and Petermann, M. L. (1952). Diabetes, 1, 28.

Rigas, D. A., and Heller, C. G. (1951). J. clin. Invest., 30, 853.

Riva, G. (1959). Schweiz. med. Wschr., 89, 610.

Routh, J. I., Knapp, E. L., and Kobayashi, C. K. (1948). J. Pediat $\frac{\rho}{3}$ 33, 688.

Rundles, R. W., Cooper, G. R., and Willett, R. W. (1951). J. cling Invest., 30, 1125.

Salteri, F., Cirla, E., and Bonomo, E. (1959). Rass. Fisiopat. clin. ter., 31, 130.

Schmidt, H. W. (1953). Klin. Wschr., 31, 985.

Schneiderbaur, A., and Rettenbacher, F. (1958). Wien. med. Wschs 108, 802.

Sellers, A. L., and Marmorston, J. (1956). J. Lab. clin. Med., 47, 248

Slater, R. J., and Kunkel, H. G. (1953). Ibid, 41, 619.

Smithies, O (1955), Biochem. J., 61, 629.

Soulier, J.-P. (1953). Presse méd., 61, 49.

Suenderhauf, H., and Wunderly, C. (1953). Gynaecologia (Base $\overrightarrow{\widehat{S}}$

Webb, T., Rose, B., and Sehon, A. H. (1958). Canad. J. Biochem. 36, 1159.

Wiedermann, D. (1953). Lék. Listy, 8, 468.

Wolvius, D., and Verschure, J. C. M. (1957). J. clin. Path., 10, $8 \dot{\theta}$

Wunderly, C., and Caspani, R. (1954). Minerva med. (Torino) parf? sci., 45 (1), 909.

\section{ADDENDUM}

Since submitting this paper for publication, Dr. M Piscator, of the Institute of Hygiene, Karolinsk Institute, Stockholm, has kindly provided us wit the opportunity of examining the urinary proteins from two cases of chronic cadmium poisoning. In both instances a post- $\gamma$ protein was detected. 